\title{
Relevance of animal models to human eating disorders and obesity
}

\author{
Regina C. Casper • Elinor L. Sullivan • Laurence Tecott
}

Received: 6 February 2008 / Accepted: 7 February 2008/Published online: 4 March 2008

(C) Springer-Verlag 2008

\begin{abstract}
Background and rationale This review addresses the role animal models play in contributing to our knowledge about the eating disorders anorexia nervosa (AN) and bulimia nervosa (BN) and obesity.

Objectives Explore the usefulness of animal models in complex biobehavioral familial conditions, such as AN, $\mathrm{BN}$, and obesity, that involve interactions among genetic, physiologic, psychological, and cultural factors.

Results and conclusions The most promising animal model to mimic AN is the activity-based anorexia rodent model leading to pathological weight loss. The paradigm incorporates reward elements of the drive for activity in the presence of an appetite and allows the use of genetically modified animals. For BN, the sham-feeding preparation in rodents equipped with a gastric fistula appears to be best suited to reproduce the postprandial emesis and the defects in satiety. Animal models that incorporate genes linked to behavior and mood may clarify biobehavioral processes underlying $\mathrm{AN}$ and $\mathrm{BN}$. By contrast, a relative abundance of animal models has contributed to our understanding of human obesity. Both environmental and genetic determi-
\end{abstract}

R. C. Casper $(\bowtie)$

Department of Psychiatry and Behavioral Sciences,

Stanford University School of Medicine,

401 Quarry Road,

Stanford, CA 94305-5723, USA

e-mail: rcasper@stanford.edu

E. L. Sullivan $\cdot$ L. Tecott

Department of Psychiatry,

University of California, San Francisco,

1550 4th Street,

San Francisco, CA 94143-2822, USA nants of obesity have been modeled in rodents. Here, we consider single gene mutant obesity models, along with models of obesigenic environmental conditions. The contributions of animal models to obesity research are illustrated by their utility for identifying genes linked to human obesity, for elucidating the pathways that regulate body weight and for the identification of potential therapeutic targets. The utility of these models may be further improved by exploring the impact of experimental manipulations on the behavioral determinants of energy balance.

Keywords Animal model - Anorexia nervosa - Obesity · Gene regulation · Eating $\cdot$ Gender $\cdot$ Bulimia nervosa

\section{Introduction}

The purpose of this paper is to explore how simulating human conditions, such as anorexia nervosa (AN), bulimia nervosa $(\mathrm{BN})$, and obesity, in animals can contribute to identifying etiological and genetic factors and enhance our knowledge of the mechanisms underlying these disorders. We will start by discussing the utility of animal models for understanding $\mathrm{AN}$ and $\mathrm{BN}$ and will conclude with a discussion of the usefulness of animal models in studying the most common disorder related to eating: obesity. For each of the conditions, we will first describe their essential clinical features and consider which behavioral or physiologic signs lend themselves to meaningful testing in laboratory studies and which aspects of the disorders might be difficult to mimic in animals. This will be followed by a review of the utility and limitations of existing animal models relevant to each of the human conditions. 


\section{Anorxia nervosa and bulimia nervosa}

\section{Diagnostic criteria of AN and BN}

The DSM IV (DSMI 1994) lists AN and BN as "eating disorders." AN falls into experimentally well supported categories, the restricting and bulimic subtype (Casper et al. 1980; Strober 1980), while the distinction between the binge eating/purging subtype and the nonpurging subtype of $\mathrm{BN}$ remains largely descriptive. The current criteria for AN acknowledge the deliberate personal element in the "refusal to maintain a normal weight for age and height." Unlike AN, with its long tradition and history, BN was not clinically described as a syndrome until 1979 (Casper 1983; Russell 1979). Both disorders are now subsumed under the umbrella term "eating disorders," even though eating as a function is intact in AN.

\section{Epidemiology of AN and BN}

AN is a rare familial (Strober and Humphrey 1987) and predominantly female condition. About 4-6\% of adolescent cases occur in males, while between $8 \%$ and $12 \%$ of $\mathrm{BN}$ cases occur in males. In contemporary Western Society, the wish for weight loss and efforts to reduce food intake remain the most powerful triggering and sustaining influences. Nonetheless, the teenage prevalence of at most $1 \%$ for $\mathrm{AN}$ and 3-4\% for BN (Hudson et al. 2007) in view of the high $(80 \%)$ frequency of dieting practices in teenage or young adult women (Nylander 1971) and the evidence for familial transmission in AN suggest that factors other than dieting must be involved in the pathophysiology. The incidence of AN has not risen significantly in the past 50 years, whereas $\mathrm{BN}$ has become more common.

\section{Phenomenology of $\mathrm{AN}$ and $\mathrm{BN}$}

A necessary feature of eating disorders, with no clear equivalent in animal behavior, is the personal decision to curtail food intake or to eat little. Even if, in contemporary culture, dieting to improve body shape appears to be the most powerful trigger of eating disorders, historically, any kind of calorie-deficient food intake leading to a catabolic state and resulting in weight loss, for example, fasting for religious reasons or weight loss due to illness, have been associated with AN (Casper and Davis 1977). Eventually, the individual makes a deliberate decision to perpetuate the food restriction. This feature is without a parallel in animals.

Symptoms in AN

Hunger, appetite, and weight loss The extent to which "eating" is impaired in $\mathrm{AN}$ or $\mathrm{BN}$ and the nature of the impairment are important questions to consider because their answers guide the methodologies used in animal models. The restricting form of AN is characterized by voluntary reduction in food intake with no significant disturbance in appetite (Garfinkel 1974); thus, the term "anorexia" or loss of appetite is a misnomer. The presence of hunger is reflected in thoughts and dreams of food and activities like baking and handling food, similar to experiences in starving individuals (Casper and Davis 1977). Persons with the binge eating or bulimic form of AN sometimes experience a voracious appetite and eat large amounts of food. In bulimic AN, compensatory behaviors, most commonly vomiting the ingested food or excessive exercise, are used to prevent weight gain. Despite intermittent food consumption, individuals with bulimic AN lose weight due to emesis, albeit not to the same low level as those with restricting AN. Significant loss of weight below $85 \%$ of normal weight for age and height or a body mass index (BMI) $<18$ are symptoms of AN (Hebebrand et al. 2004). The BMI expresses body weight in kilograms $(\mathrm{kg})$ divided by height in meters $(\mathrm{m})$ squared and, in adults, correlates strongly with total body fat content. In children and young adolescents who are still growing, the Iowa growth charts provide more accurate normative values. AN is the only condition known to lead to pathologically low weight without "physical illness."

Endocrine disturbances Primary amenorrhea or, in postpubertal females, the absence of menstrual periods for a minimum duration of 3 months are clinical symptoms necessary for the diagnosis, indicating significant physiological adaptations, for example, AN is associated with hypoleptinemia (van Elburg et al. 2007), as a result of weight loss. In most individuals, the hypothalamic-gonadal adaptations that lead to amenorrhea can be related to weight loss and the catabolic state. In a minority of patients who become amenorrheic after moderate weight loss, additional factors, such as stress, seem to influence hypothalamicgonadal function. Numerous endocrine changes that affect virtually every regulatory system in AN reflect the body's adjustment to prolonged undernutrition and malnutrition. The more severe the weight loss, the more pronounced and widespread are the adaptations in physiological and endocrine systems. These physiological adaptations can become life threatening, especially in the binge-eating/ purging subtype, but all are reversible and normalize with adequate nutrition, weight gain, and normalization of eating patterns (Casper et al. 1977).

Drive for activity, restlessness Unlike the fatigue and motor slowing typically observed in semistarvation, individuals who are vulnerable to AN tend to become energized and display normal-to-high activity levels and mental alertness 
when they lose weight (Casper 1998b). The drive for activity allows some individuals with $\mathrm{AN}$ to engage in excessive exercise. Higher than normal activity levels in AN have been confirmed experimentally (Casper et al. 1991; Klein et al. 2007; Pirke et al. 1991). We have suggested that the drive for activity, restlessness, and the mental alertness during the starvation state represent core symptoms of AN and, therefore, ought to be included as diagnostic criteria (Casper 2006). The escalation in restlessness and the drive for activity are closely interrelated with the caloric deprivation and the catabolic state and decline with food intake in both subtypes (Hebebrand et al. 2003a). Individuals who reported excessive exercise reported lower minimum BMI, younger age at interview, higher scores on anxiety, perfectionism, and eating disorder symptom measures (Shroff et al. 2006).

Denial of illness, body image disturbances, and other psychological symptoms The ideation typical for AN, the so-called anorectic attitude, consisting of denial of illness and fear of fatness, makes its appearance at a weight loss of about $15 \%$ of previous body weight based on reports from individuals with AN (Casper and Davis 1977). The experience of sustained physical and mental energy likely supports the common assertion that "nothing is wrong." The so-called body image disturbance, in essence an overestimation of body size and depth despite body wasting, has been shown to be related to denial (Casper et al. 1979; Crisp and Kalucy 1974).

Psychiatric and personality disorders show significant variability and range from adjustment disorders to anxiety disorders, obsessive-compulsive disorders, and depressive disorders. Binge eating in AN has been shown to predict later substance use (Strober et al. 1996). Care must be taken during treatment to distinguish the psychological sequelae of malnutrition from a comorbid psychiatric disorder. The subtypes show different personality features. The restricting subtype is typically associated with emotional, cognitive, and social inhibitions, including perfectionist and obsessive traits, whereas the bulimic subtype tends to be extroverted but emotionally labile to the point of being impulsive (Casper et al. 1992). In the largest study to date, $15 \%$ of AN patients qualified for obsessive compulsive personality disorder, $15 \%$ for obsessive compulsive disorder, and $16 \%$ for both disorders; however, 54\% reported neither (Halmi et al. 2005).

Animal models in eating disorders

The suitability and limitations of animal models for investigating eating disorders have been discussed previously in the literature. Smith (1989) in his excellent review conceptualizes several types of animal models: the etiologic, based on the same cause; the isomorphic, based on similar forms; the mechanistic; and the predictive model. Obesity research has made use of all models, including the etiologic, for example, through investigating genetic and dietary determinants of overweight. By contrast, isomorphic models, animal preparations that recreate conditions in which different etiologies produce similar symptoms such as the hyperphagia observed in BN, binge-eating syndrome and in obesity have been favored in eating disorders. For $\mathrm{AN}$, characteristics such as female sex, puberty, decreased food intake associated with significant weight loss, and neuro-endocrine adaptations would seem fundamental to modeling the syndrome in animals. Another detailed and informative discussion of environmentally induced models, spontaneous mutations, and genetic knock-out mouse models of AN has been published by Siegfried et al. (2003). Central to their article was the notion of "anorexia," i.e., reduced food intake as a defining symptom.

\section{Animal models of AN}

Feeding restrictions: activity-based anorexia One of the most suitable animal models has been the "activity/stress" or "activity-based anorexia" model in mice and rats (Routtenberg and Kuznesof 1967) originally developed to investigate the effects of stress in food intake. This model reproduces core behavioral correlates of $\mathrm{AN}$, the restricted food intake in the presence of hunger, the weight loss, the drive for activity, and the physiologic consequences of undernutrition (Pirke and Ploog 1987). Briefly, rats or mice on a restricted feeding schedule, when given access to a running wheel, show excessive wheel running leading to a decline in body weight; amenorrhea; and, ultimately, death. Maximal wheel running occurs when animals are restricted to one time-limited period of food availability per day (Kanarek and Collier 1983). Initially, animals compensate by increasing the amount of food eaten during the period of restricted access; however, with increased activity, animals no longer increase the amount consumed. "Activity/stress" model animals develop starvation-induced immunodeficiency and atrophy of the spleen and thymus (Watanabe et al. 1992), as well as stress ulcers (Paré 1975), complications not observed in individuals with AN. In this model, administration of L-tryptophan and serotonin agonists and antagonists reduced physical activity (Pirke et al. 1993) and tyrosine supplementation improved appetite and cognitive function and delayed the onset of fatigue in mice (Avraham et al. 2001). Just as activity levels and restlessness in AN are sustained by a negative energy balance and low plasma leptin concentrations (van Elburg et al. 2007), hypoleptinemia (Hebebrand et al. 1997) and low glucose levels increase wheel running in rats (Takeda et al. 2003). 
Conversely, leptin administration decreases wheel running in rats (Hillebrand et al. 2005). Gelegen et al. (2007) compared the C57BL/6J and DBA/2J strains of inbred mice, which display low and high levels of anxiety and activity-related behaviors, respectively, in the activity/stress model. The trajectory of the decline of serum leptin levels was steeper than in the $\mathrm{C} 57 \mathrm{BL} / 6 \mathrm{~J}$ strain and correlated with activity in the DBA/2J strain, suggesting that leptin dynamics may influence the development of activity anorexia and conceivably might be involved in generating the drive for activity in AN. Nergardh et al. (2007) reported elevated levels of neuropeptide Y (NPY) mRNA in the hypothalamic arcuate nucleus; intracerebroventricular NPY infusion paradoxically reduced food intake in activity-based anorexia rats.

Epling and Pierce (1988) have pointed to the survival value of the relationship between eating and running. During times of food scarcity, animals either hibernate and conserve energy or become mobile and migrate. Individuals with AN remain remarkably mentally alert and animated, suggesting regionally intact brain metabolism despite cachexia (Casper 2006). Van Kuyck et al. (2007) have monitored cerebral metabolic changes in a positron emission tomography study in the activity-based anorexia model. The investigators found a positive correlation between body weight loss and cerebral metabolism in the cingulate cortex and the adjacent motor and somato-sensory cortex, but hypometabolism in the insular cortex and ventral striatum, suggesting site-specific differences in brain metabolism.

Food restriction alone leading to a catabolic state has been modeled in animals and can serve to study the starvation-induced physiological and endocrine changes and their reversibility (Casper 1998a; Fetoui et al. 2006; Mahoney et al. 2006). The literature describing experimental undernutrition in animals is too vast to be covered here. Recent studies describing the involvement of several genes in regulating differences in the physiological adaptations to dietary restriction, however (Rikke and Johnson 2007), offer possibilities for investigating variations in the human response to fasting.

Stress-induced appetite loss Animal models simulating loss of hunger are less well suited to reproduce AN, for the simple reason that they are based on an erroneous assumption of loss of appetite. The wasting pig syndrome has been proposed by Treasure and Owen (1997) as a model of AN and stress-induced appetite loss. Exposed to adverse conditions, pigs bred for extreme leanness after weaning may fail to feed normally and can develop the wasting pig syndrome. These pigs are more active than the other animals. The syndrome can be prevented and treated by administra- tion of serotonin $\left(5 \mathrm{HT}_{2}\right)$ receptor antagonists (Kyriakis et al. 1990). Through breeding strategies, Andersson et al. (1994) have also shown that chromosome 4 in pigs, corresponding to chromosome 1 in humans, has a large effect on fat deposition. Another type of stress, restraint, can also reduce food intake in rodents (Wang 2002); "restraint," however, is not a symptom of AN. The stress model might apply to risk factors for AN because stressful situations may set off dieting efforts leading to weight loss.

Separation models Here, physical separation acts as a stressor to induce a depression-like condition with decreased feeding, weight loss, and cognitive changes. Mice are housed in one cage but separated by Plexiglass partitions, where they can see and smell each other, and are transferred to a common cage for feeding. Separation reduces food intake and causes severe weight loss and impaired learning in a $\mathrm{T}$ maze task. This condition was associated with depletion and increased turnover of hippocampal and hypothalamic catecholamines. Increasing tyrosine availability restored performance to control levels (Hao et al. 2001). Depressive disorders with loss of appetite are uncommon as direct precursors of AN. In AN, serotonin agonists or antagonists have been found to be minimally effective, and tyrosine administration has not undergone placebo-controlled trials for the treatment of AN. To date, no pharmacological agent has been approved by the FDA for the treatment of AN.

Genetic animal models Despite a wealth of studies, no consistent associations between susceptibility genes and $\mathrm{AN}$ or BN have been reported (Klump and Gobrogge 2005). A review of genetic linkage and association studies in eating disorders is beyond the scope of the article. We will give here an example of how the behavior of genetically modified animals can inform the search for candidate genes. Observations of altered feeding behavior leading to increased body weight in brain-derived neurotrophic factor (BDNF) knockout mice and reports that intraventricular administration of BDNF in rats resulted in reduced feeding and weight loss prompted Ribases et al. (2003) to study the $\mathrm{BDNF}$ gene in AN. The investigators observed a strong association between restricting $\mathrm{AN}$, as well as minimum body weight, and an amino acid substitution within the BDNF precursor protein (Val66Met); they replicated the findings in an independent sample (Ribases et al. 2005). Because the BNDF mutation would be expected to increase food intake, the finding appears counterintuitive. Recently, other researchers have failed to find evidence for a preferential transmission of the 66Met allele of BDNF in AN (Dardennes et al. 2007). With regard to appetite and energy regulatory peptides, no associations between AN or BN have been found with the ghrelin gene (Monteleone et al. 2006b) and for AN in single nucleotide polymor- 
phisms (SNPs) in the leptin receptor (Quinton et al. 2004). For the bulimic subtype of AN, only, two polymorphisms have been reported, one in the Leu72Met SNP of the preproghrelin gene and another for the Ala67Thr of the Agouti-related protein (AGRP) gene (Dardennes et al. 2007).

Johansen et al. (2003) have suggested that the anorexic (anx/anx) mouse, a spontaneous mouse mutation, can be used for studying food intake and energy expenditure as a model of AN. "Anorexia" (anx) is a recessive mutation that causes decreased food intake leading to death 20 30 days after birth in homozygous mice. The mice have reduced serum leptin levels and show abnormalities in the orexigenic (NPY/AGRP neurons) and the anorexigenic [pro-opiomelanocortin (POMC)/cocaine- and amphetaminerelated transcript (CART) neurons] pathways. Besides their cachectic appearance, these mice show body tremors, ataxia, head weaving, and hyperactivity. The investigators (Fetissov et al. 2005) have also studied contactin knock-out mice, which resemble in phenotype the "anorexia" mouse and show similar changes in central pathways. In view of the normal motility, the preserved appetite and normal regulation of plasma leptin levels (Eckert et al. 1998) in individuals with AN, the neurological deficit/starvation syndrome in these mutant lines bear little resemblance to the human condition.

To study hedonic and motivational responses to food intake, Papaleo et al. (2007) created a mu-opioid receptor (MOR) -deficient mouse. MOR-deficient mice showed lower levels of food-driven nose-poking but no cognitive abnormalities. Polymorphisms have not been reported for the mu receptor but have been found for the delta-1 opioid receptor gene (Brown et al. 2007), pointing to the potential usefulness of opioid receptor-deficient mice for studying changes in appetitive behavior in AN. In summary, the symptoms of AN are most closely reproduced by the activity stress rodent model. In the future, this model might yield valuable information through the inclusion of genetically modified animals. Models employing food restriction with stress-induced appetite loss leading to weight loss provide a poor fit for the human syndrome. To date, experimental manipulation of animals has not significantly contributed to our knowledge about the etiology AN. In the future, genetic models might prove more useful.

\section{Bulimia nervosa}

$\mathrm{BN}$ is characterized by recurrent episodes of binge eating with a sense of lack of control over eating and associated with recurrent compensatory behaviors such as vomiting, excessive exercise, and laxative or diuretic misuse. Selfevaluation is unduly influenced by body shape and weight.
In the nonpurging subtype of $\mathrm{BN}$, the person uses fasting or excessive exercise to counteract the surplus intake of food.

Hunger, appetite, and weight loss in BN As a result of chronic dieting, individuals with $\mathrm{BN}$ continuously contend with hunger sensations and thoughts of seeking food or strategies to avoid food to the point of not being able to attend to other matters. Eating large amounts of food on a daily basis and the loss of food through postprandial vomiting interfere with satiety signals (Zimmerli et al. 2006). Instead of regular meals during daytime, efforts at avoiding food at all costs, punctuated by nocturnal eating binges followed by vomiting, produce an unpredictable and chaotic eating pattern. The persistent wish to eat reinforces the sense of lack of control over food described by individuals with $\mathrm{BN}$ as "addiction to food." The ability to regurgitate and to vomit food, in part self-taught and habituated, is a characteristic of BN and may be familial because habitual regurgitation or rumination has been described in relatives (Parry-Jones 1994). Body weight tends to remain within the normal to high normal range (BMI between 18-30).

Psychological disturbances Both subtypes of BN have a high comorbidity with mood disturbances, ranging from minor to marked psychopathology. In outpatient populations, about two thirds of individuals with BN qualified for an affective disorder (Brewerton et al. 1995). Substance use disorders are associated with $\mathrm{BN}$, albeit less frequently than affective disorders (Hatsukami et al. 1984). Individuals with $\mathrm{BN}$ are more stress-sensitive than individuals with AN; minor stressful experiences can trigger eating binges.

Genetic studies in $B N$ Genetic association and linkage studies in $\mathrm{BN}$ have examined the relationship between traitbased variations in phenotypes such as affective instability or anxiety as a source of negative emotions, as well as eating pattern phenotypes to variability in candidate genes. Specifically, the contribution of the serotoninergic system to anxious and depressive traits, which may be partially responsible for the variability in the psychopathology of BN, has been explored (Frieling et al. 2006; Monteleone et al. 2006a). With respect to other regulators (Ribases et al. 2004), the Met66 allele of the Val66Met of the BDNF variant was found to be associated with $\mathrm{AN}$ and $\mathrm{BN}$. To our knowledge, a model of BN based on single gene mutations or quantitative trait loci in animals has not been developed.

Animal models of BN

Nearly all models focus on identifying potential environmental determinants of binge eating behavior. The rela- 
tionship between prolonged food restriction and overeating or binge eating once food becomes available in a normal population is well documented from the Minnesota Starvation experiments (Keys et al. 1950). Stress and negative emotions have been found to contribute to binge eating in $\mathrm{BN}$.

Stress-induced hyperphagia Periods of restricted feeding in rats followed by free access to food mimic to some extent the intermittent self-imposed fasting and the yielding to food. When this protocol was combined with acute stress in the form of a foot shock, animals became hyperphagic once they had access to highly palatable food; if only chow was available, overeating did not occur. Recurrent cycles of restriction followed by stress regularly increased food intake (Hagan et al. 2002). Inoue et al. (2006) have proposed that the hyperphagia induced by space restriction of rats following time-restricted feeding could serve as a model of stress-induced eating in normal subjects and the disorganized eating of individuals with BN, nonpurging type. This paradigm may identify pathways through which negative emotions trigger abnormal eating responses.

Hyperphagia due to impaired satiety

The defect in satiety mechanisms in BN, aggravated by postprandial vomiting or purging, can be modeled in the sham-feeding rat (Davis and Campbell 1973; Mook 1963). A gastric fistula is placed to have the ingested liquid food drain from the stomach, thereby minimizing contact of food with the gastric and intestinal mucosa, producing a reversible, acquired defect in satiation. As expected, these rats eat abnormally large meals. With repetition, the interval time shortens and the size and length of the sham-fed meals increase, suggesting that the rat is learning to eat more under conditions of defective satiation. Such binge meals were also affected by the palatability of the diet, suggesting that, in the rat, oral sensory stimulation influenced sham feeding, given the lack of caloric absorption. In these experiments, rats maintained weight by being fed outside the sham-feeding tests.

\section{Estradiol and satiation}

Bulimic AN is associated with amenorrhea, raising the possibility that low estrogen levels may contribute to periodic bouts of overeating. Asarian and Geary (2007) have in fact shown in ovariectomized rats that estradiol acting on estrogen receptor (ERalpha) signaling markedly increased the satiating potency of intraduodenal lipid infusions via a cholecystokinin-dependent mechanism.
Meal patterning and binge eating

The psychopharmacological and neural circuit influences on meal patterns in rodents have been reviewed by Clifton (2000). Meal patterning appears to be regulated through a multitude of redundant mechanisms. It is therefore not surprising that drugs are only partially effective for controlling eating binges and that fluoxetine, only, has been approved for the treatment of BN. To replicate meal patterning of food binges in rodent models, the precise consumption pattern in BN needs to be known. Intake patterns in BN are still being studied by Kissileff et al. (2007), who confirmed recently that "rapid food consumption" during a binge occurs even at different rates of food presentation. Patients with BN ate equally large amounts at a slow rate of food presentation as at a fast rate, as opposed to control subjects who ate less when food was presented at a slow rate.

Other environmental models of bingeing use various combinations of restriction/refeeding cycles and/or stress, limited access to optional foods, and eating induced by schedules of reinforcement maintaining operant behavior (Corwin 2006). For example, limited access to highly palatable shortening established similar consumption of shortening during the limited time period $(2 \mathrm{~h})$ and the 24$\mathrm{h}$ ab libitum period in rats. These models address the consumptive side of $\mathrm{BN}$, and they are suitable for testing drug effects on food intake behavior. Nevertheless, mindful of the differences in the pharmacologic responses between humans and rodents, new drug development for the treatment of $\mathrm{BN}$ concentrates on drug testing in human subjects (Naessen et al. 2007).

In summary, as far as we know, no models of overeating have reproduced the voluntary elements in the periodic daytime food restriction; the sense of lack of self-control; or, except for the sham-feeding model, the emesis following the binge-eating bouts of $\mathrm{BN}$. The regurgitation model in gorillas proposed by Gould and Bres (1986) appears to be a better model for childhood rumination disorder than for BN. Food availability and palatability play a significant role in the disordered eating of BN patients. For instance, imposing external controls through hospitalization with regular meals of hospital food effectively eliminates binge eating in individuals with $\mathrm{BN}$.

In conclusion, the symptom constellation of overeating, postprandial vomiting, and impaired satiety can be modeled best in the sham-feeding animal. Rodent models of stress-induced hyperphagia, the contribution of estradiol, meal patterning, operant schedules of food access, and food palatability may be useful for drug development. For BN, specifically, laboratory experiments in humans continue to yield significant new information (Kissileff et al. 2007). 


\section{Obesity}

\section{Clinical features of obesity}

Obesity is defined as a state of excess body fat. Because accurate body fat measurements require specialized procedures, obesity is commonly defined in terms of body weight (Ogden et al. 2007). The National Institutes of Health classifies an adult as obese if their BMI is 30 or greater and overweight if their BMIs are between 25.0 and 29.9 (NIH 1998; Ogden et al. 2006). Children and adolescents (age 2-19) are considered overweight if their BMIs are in the 95th percentile for their age and gender based on growth charts from the Center for Disease Control and Prevention (Kuczmarski et al. 2002).

\section{Epidemiology of obesity}

The increasing prevalence of overweight and obese individuals is a global problem that affects over a billion adults and 17.6 million children under the age of 5 (Flegal et al. 2002; Strychar 2006; Waxman 2004). Weight gain has escalated over the past two decades, such that only a minority $(<34 \%)$ of adult Americans are currently considered to have a healthy BMI (Ogden et al. 2006). Moreover, $17 \%$ of children and adolescents in the USA are currently overweight (Ogden et al. 2006). Obesity varies by age group, gender, and race-ethnic group, with elevated rates observed in individuals that are older (up to age 80), female, or African American (Ogden et al. 2006).

The increasing prevalence of obesity has large implications for the health of the human population. Obesity is associated with overall increases in morbidity and mortality (Paffenbarger et al. 1993), resulting from an increased risk of diabetes mellitus (Colditz et al. 1990; Folsom et al. 1996; Kujala et al. 1994; World Health Organization 2000), heart disease (World Health Organization 2000; Hamm et al. 1989; Klein et al. 2004; Kujala et al. 1994; Manson et al. 1990; Rimm et al. 1995; Willett et al. 1995), hypertension (World Health Organization 2000; Kujala et al. 1994), stroke (World Health Organization 2000), dyslipidemia (World Health Organization 2000), pulmonary diseases (World Health Organization 2000), colon cancer (Giovannucci et al. 1995), and breast cancer (Ziegler et al. 1996). If obesity rates rise at the current pace, obesity will exceed smoking as the leading preventable cause of death in the USA within the next few years (Mokdad et al. 2004).

\section{Etiology of obesity}

Obesity occurs when individuals consume more calories than they expend over a prolonged period of time, resulting in storage of excess calories in body fat. Obesity is a multifactorial disease caused by environmental and genetic factors and the complex interactions among them. The recent surge in the prevalence of obesity is unlikely to have resulted solely from genetic factors, as the genetic composition of the human population has not changed substantially during this brief time period. Environmental factors and lifestyle trends toward decreased physical activity and increased caloric intake contribute substantially to the increasing prevalence of obesity. Factors such as the availability of diverse, highly palatable, energy-dense foods; large portion sizes; and increased snacking are likely to contribute to increased calorie consumption. As there is no indication that basal metabolic rates have declined over the last two decades (De Lorenzo et al. 2001; Frankenfield et al. 1998), this is unlikely to account for the escalating prevalence of obesity. However, there is ample evidence that decreased physical activity contributes significantly to the obesity epidemic (Levine 2004; Speakman and Selman 2003). The modern "obesigenic environment" has minimized the need for physical activity and enabled ready access to energy-dense food in quantities that exceed individual needs.

Although genetic factors are unlikely to account for the increased prevalence of obesity, they play a large role in determining who becomes obese. Some groups of individuals, such as Pima Indians and Pacific Islanders, are particularly prone to weight gain (Friedman 2003; Ravussin and Gautier 1999). Up to $70 \%$ of the variability in human adiposity results from genetic endowment, as estimated in twin, adoption, and family studies (Bell et al. 2005; Farooqi and O'Rahilly 2005b; Hebebrand et al. 2003b). Linkage studies suggest that many distinct genetic loci contribute to the heritability of obesity. Currently, over 250 genes, markers, or chromosomal regions have been shown to be associated with human obesity, including mutations of genes encoding leptin, the leptin receptor, and the melanocortin 4 receptor $\left(\mathrm{MC}_{4} \mathrm{R}\right)$ (Rankinen et al. 2002).

Obesity is associated with disordered eating

Obesity is associated with two eating disorders: bingeeating disorder (BED) (Corwin and Buda-Levin 2004) and night-eating syndrome (NES) (Stunkard and Allison 2003b). Binge eating is defined as "eating during a discrete period of time (e.g. within any 2 hour period), an amount of food that is definitely larger than most people would eat during a similar period of time under similar circumstances" (DSM 2000). Binge eating is a complex behavior associated with feelings of loss of control, disgust, guilt, depression, and embarrassment (Corwin and Buda-Levin 2004). Both BED and BN are characterized by binge eating. However unlike $\mathrm{BN}$, binge eating in BED is not accompanied by compensatory behaviors such as purging, 
fasting, or excessive exercise (Marcus et al. 1985). BED is further defined as binge eating that occurs twice per week for at least 6 months (Stunkard and Allison 2003a). BED is associated with early onset of obesity, increased frequency of weight cycling, greater susceptibility to weight regain, and psychiatric disturbances such as anxiety disorders, depression, and substance abuse (Striegel-Moore and Franko 2003). The most common current treatments, which include antidepressants and cognitive behavioral psychotherapy, are only modestly successful for the long-term reduction of binge eating (Stunkard and Allison 2003a; Yanovski 1993). Interestingly, mutations in the $\mathrm{MC}_{4} \mathrm{R}$ are associated with an increased incidence of BED (Branson et al. 2003).

As BED has been recently introduced into psychiatric nomenclature, epidemiologic research on the disorder is limited. Preliminary studies indicate that BED occurs more frequently than either AN or BN (McElroy et al. 2007). In the general population, BED prevalence estimates range from $1.5 \%$ to $5 \%$ in women and $1 \%$ to $3 \%$ in men (StriegelMoore and Franko 2003; Yanovski 1993). The prevalence of BED is higher in obese individuals, with $20-30 \%$ of obese individuals seeking treatment displaying BED (Jarosz and Metzger 2002; Striegel-Moore and Franko 2003; Yanovski 1993). Thus, binge eating may be an important contributor to the development and maintenance of obesity in a subgroup of obese individuals.

NES was first described by Stunkard et al. in 1955 (1955) and is defined as consumption of more than $50 \%$ of ones' daily caloric intake at night. NES is also characterized by morning anorexia and insomnia (Stunkard and Allison 2003b) and with alterations in circadian regulation, characterized by a delay in phase onset. Individuals with NES have difficultly falling asleep and difficulty maintaining sleep with awakenings associated with food intake (Stunkard and Allison 2003b). The amount of food consumed by individuals during each night-feeding episode was found to be approximately the same size as a moderate snack (approximately 270 calories), smaller than the amount of food consumed by individuals with BED and $\mathrm{BN}$ during an eating binge (Birketvedt et al. 1999). NES is comorbid with depression (Gluck et al. 2001) and is associated with increased weight gain and obesity (Grilo and Masheb 2004). Individuals with NES have been reported to show attenuated hypothalamic-pituitary-adrenal axis responses to corticotropin-releasing hormone (Birketvedt et al. 2002). They have also been reported to have elevated circulating levels of cortisol (Birketvedt et al. 1999) and ghrelin (Rosenhagen et al. 2005) and a reduced nocturnal rise in levels of melatonin and leptin (Birketvedt et al. 1999).

NES is estimated to occur in $1.5 \%$ of the general population and is reported to be higher in obese individuals (Rand et al. 1997). Prevalence of NES in obesity clinics and in obese individuals seeking surgical treatment is estimated to range from $9 \%$ and $43 \%$ (Rand et al. 1997; Stunkard and Allison 2003b). In contrast to the limited evidence for a familial tendency in BED, there is evidence for a strong aggregation of NES in families. (Lundgren et al. 2006; Stunkard and Allison 2003b). Recent evidence suggests that treatment with the selective serotonin reuptake inhibitor, sertraline, is effective in reducing nighttime eating and promoting weight loss in obese individuals with NES (O’Reardon et al. 2006; Stunkard et al. 2006).

\section{Animal models of obesity}

Though further study of the human population is critical to understanding obesity and assessing potential therapeutic interventions, many mechanistic questions require the use of animal models. Animal models have contributed substantially to current knowledge of body weight regulation and obesity. Studies in animals have provided key insights into the central and peripheral biological pathways regulating body weight and energy balance. Furthermore, animal models have been effectively used to explore environmental influences on body weight and energy balance and have also been critical for the identification of therapeutic targets and for evaluating novel obesity treatments.

The characterization of rodent obesity syndromes arising spontaneously from single gene mutations has played an important role in obesity research. Currently, 10 spontaneous single-gene mutations that confer an obesity phenotype have been characterized (Speakman et al. 2007). The prototypical example is the obese $(o b / o b)$ mouse. These mice are profoundly obese, hyperphagic, and diabetic and have reduced locomotor activity and metabolic rates (Garthwaite et al. 1980; Mayer et al. 1953; Pelleymounter et al. 1995). Initial parabiosis experiments revealed that $o b / o b$ mice lack a circulating factor produced by their wildtype litter mates (Coleman 1973, 1978). Friedman and colleagues used positional cloning to identify this factor as the adipocyte hormone leptin (Friedman et al. 1991; Zhang et al. 1994). Additional studies revealed that leptin treatment reverses obesity in $o b / o b$ mice by normalizing food intake, locomotor activity, and metabolic rate (Halaas et al. 1995; Pelleymounter et al. 1995). The diabetic ( $d b / d b)$ mice and Zucker fatty $(f a / f a)$ rats display similar obesity phenotypes, but instead of lacking leptin, these animals bear loss-of-function mutations of leptin receptor genes (Elmquist et al. 1999). These studies provide solid evidence that leptin signaling is critical for body weight regulation, a conclusion highlighted by the morbid obesity seen in rare individuals with leptin null mutations (Farooqi and O'Rahilly 2005a).

In addition to the insights gained from analysis of obesity syndromes arising from spontaneous mutations, planned genetic manipulations generated by transgenic and gene 
targeting technologies have contributed substantially to obesity research. These technologies enable the selective manipulation of the expression levels of particular genes. Most commonly, investigators have sought to either overexpress or to eliminate the expression of a particular gene. Overexpression has been typically achieved by the introduction of a transgene consisting of promoter sequences for the gene of interest upstream from the coding sequence of the gene (Speakman et al. 2007). Conversely, "knockout mice" bearing null mutations that completely eliminate expression of the gene of interest have been generated using genetargeting methodologies.

The utility of gene knockout mice in obesity research is illustrated by studies of the central melanocortin system, which plays a prominent role in regulating energy homeostasis (Coll 2007). The central melanocortin system is a collection of neural circuits including arcuate nucleus hypothalamic neurons containing POMC and CART, which act to inhibit food intake. A cleavage product of the POMC precursor, $\alpha-\mathrm{MSH}$ acts as an agonist at melanocortin-3 receptor $\left(\mathrm{MC}_{3} \mathrm{R}\right)$ and $\mathrm{MC}_{4} \mathrm{R}$ to inhibit food intake and weight gain (Cone 2005). Within the arcuate nucleus, another pathway exists with opposing effects on feeding. Neurons of this pathway express NPY and AGRP, which act to increase food intake. AGRP suppresses activation of the melanocortin pathway by acting as an endogenous antagonist at $\mathrm{MC}_{3} \mathrm{Rs}$ and $\mathrm{MC}_{4} \mathrm{Rs}$ (Cone 2005; Ellacott and Cone 2006).

The melanocortin system was implicated in body weight regulation by studies of obese agouti mice (Ay/a) that bear a spontaneous mutation leading to ectopic overexpression of the agouti protein (Miltenberger et al. 1997; Salton et al. 2000), which exerts an antagonist action at melanocortin receptors ( $\mathrm{Lu}$ et al. 1994). However, as there are five melanocortin receptor subtypes; it remained unclear which were involved in body weight regulation. A prominent role for the $\mathrm{MC}_{4} \mathrm{R}$ was highlighted by $\mathrm{MC}_{4} \mathrm{R}$ knockout mice, which exhibited maturity-onset obesity, overeating, hyperinsulinemia, and increased linear growth (Huszar et al. 1997). The role of the $M_{4} R$ in body weight regulation was further confirmed by pharmacologic studies showing that $\mathrm{MC}_{4} \mathrm{R}$ agonists suppress food intake and antagonists increase food intake (Kask et al. 1998a; Murphy et al. 1998; Skuladottir et al. 1999). These studies led ultimately to the discovery of mutations in the melanocortin system in obese humans (Krude et al. 1998). In contrast to the rarity of human leptin deficiency, mutations of the gene encoding $\mathrm{MC}_{4} \mathrm{R}$ are the most common known form of human monogenic obesity estimated to occur in $4-6 \%$ of morbidly obese individuals (Farooqi et al. 2003; Lubrano-Berthelier et al. 2003; Vaisse et al. 2000).

$\mathrm{MC}_{4} \mathrm{R}$ knockout mice have also implicated the $\mathrm{MC}_{4} \mathrm{R}$ in the obesigenic effects of high-fat diets (Butler et al. 2001).
$\mathrm{MC}_{4} \mathrm{R}$ knockout mice display accelerated weight gain when placed on a diet with increased fat content, due to enhanced hyperphagia and loss of the compensatory increase in metabolic rate and activity in response to high-fat diet consumption (Butler et al. 2001). Thus, the $\mathrm{MC}_{4} \mathrm{R}$ knockout mouse is important, as it led to further elucidation of the regulation of body weight by the melanocortin system, identified a potential target for obesity treatment (Butler 2006), and models a relatively common type of human obesity.

The serotonin (5-HT) system has also been strongly implicated in body weight regulation, as illustrated by the use of the serotonergic agent fenfluramine as an appetite suppressant (Blundell and Leshem 1975; Foltin and Moran 1989; Grinker et al. 1980; McGuirk et al. 1991; Rogers and Blundell 1979). Due to the limited availability of selective pharmacological agents, the relative contributions of the 14 subtypes of serotonin receptors to feeding regulation were difficult to determine. To study the contributions of the 5$\mathrm{HT}_{2 \mathrm{C}} \mathrm{R}$ to the actions of serotonin, mice lacking $5-\mathrm{HT}_{2 \mathrm{C}} \mathrm{Rs}$ were generated (Tecott et al. 1995). These animals exhibited an obesity syndrome characterized by reduced sensitivity to fenfluramine, hyperphagia, and maturity-onset obesity and enhanced susceptibility to the adipogenic and diabetogenic effects of dietary fat (Nonogaki et al. 1998; Tecott et al. 1995). These findings indicated that the 5$\mathrm{HT}_{2 \mathrm{C}} \mathrm{R}$ subtype plays a substantial role in the serotonergic regulation of body weight. Although there is no definitive evidence that variants of the $5-\mathrm{HT}_{2 \mathrm{C}} \mathrm{R}$ gene play a significant role in human obesity, the knockout studies fueled attempts to develop $5 \mathrm{HT}_{2 \mathrm{C}} \mathrm{R}$ agonist appetite suppressants, one of which is currently advancing through clinical trials (Miller 2005; Smith et al. 2006).

It is important to consider several caveats when interpreting the phenotypes of mutant mice; they include the potential for developmental compensations (Crawley 1996; Lathe 1996; Wilson and Tonegawa 1997), the influence of background genotype (Crawley 1996; Gerlai 1996; Sibilia and Wagner 1995; Simpson et al. 1997; Threadgill et al. 1995), and environmental factors such as diet and stress (Crabbe et al. 1999). Such factors can result in unanticipated phenotypes, as exemplified by the NPY knockout mouse. Even though NPY is one of the most potent orexigenic peptides (Salton et al. 2000), NPY knockout mice have normal levels of food intake and body weight (Erickson et al. 1996). Furthermore, deletion of either the NPY Y1 (Pedrazzini et al. 1998) or the Y5 (Marsh et al. 1998) receptor resulted in the paradoxical induction of obesity. Thus, the genetic studies exploring the role of NPY in body weight regulation were inconsistent with the pharmacologic studies. Because conventional gene knockout techniques result in constitutive gene deletion throughout the entire organism and throughout develop- 
ment, the interpretation of mutant phenotypes may be complicated by potential compensatory effects that do not reflect the normal adult role of the gene product.

Recent progress in mouse molecular genetic methods enables the circumvention of such problems by enabling the restriction of gene expression to particular cell types or to discrete anatomical regions. Furthermore, it is possible to manipulate the gene of interest during a specific period of the animals' life, eliminating the confounds of development compensations (Davey and MacLean 2006). One of the most common genetic strategies used today employs the Cre/loxP recombination system. This involves crossing two separate mutant mouse lines, one which expresses Cre recombinase under the control of a cell type and/ or -temporally regulatable promoter, and a second in which a critical region of the target gene is flanked by Cre recombinase recognition (loxP) sites. In mice bearing both the Cre transgene and the floxed target gene, Cre recombinase catalyzes recombination between the loxP sites, resulting in the deletion of the intervening target sequence (Davey and MacLean 2006; Ghosh and Van Duyne 2002). The target gene is deleted only in those cells expressing Cre and functions normally in all other cells of the body. Lines of mice in which Cre is under the control of an inducible promoter are used to temporally regulate when the target gene is deleted, allowing investigation of target gene function during different stages of development.

These techniques provide powerful tools for unraveling the pathways that regulate body weight. For example, Jeffrey Friedman and colleagues have used the Cre/loxP system to delete the leptin receptor from particular cell and tissue types (Cohen et al. 2001). Mice were created in which leptin receptors were removed specifically from neurons, and a correlation was found between the number of hypothalamic leptin receptors and obesity, such that mice with the lowest levels of hypothalamic leptin receptors were the most obese (Cohen et al. 2001), indicating that central leptin receptors are a direct target for leptin's anorexigenic action. A discrete central locus of leptin action on the melanocortin system was further suggested by neuroanatomical (Cheung et al. 1997) and pharmacological evidence (Kask et al. 1998b; Seeley et al. 1997). To directly test the physiologic relevance of leptin receptors expressed by POMC neurons, the cre/loxP system was again employed (Balthasar et al. 2004). Deletion of leptin receptors from POMC neurons resulted in mice that were mildly obese (Balthasar et al. 2004), indicating that leptin receptors expressed on POMC neurons are important but not solely responsible for leptin's regulation of body weight.

Animal models are also important for exploring the effects of environmental factors on body weight and obesity. One of the most studied environmental factors is diet. Understanding the effects of dietary composition on body weight regulation is critical. However, manipulating the diet of humans is very challenging. Indeed, selfreported food intake data are notoriously inaccurate (Champagne et al. 1998; DeLany et al. 2002). Studies in mice show that certain strains of mice such as C57BL/6J (Surwit et al. 1995) and DBA/2J (Alexander et al. 2006; Funkat et al. 2004) have increased susceptibility to weight gain on a high-fat diet, whereas others, such as A/J, are resistant to diet-induced obesity (Surwit et al. 1995). When outbred Sprague-Dawley rats are placed on a high-fat diet, about half become obese, while the other half are resistant to weight gain (Levin 1990; Levin and Dunn-Meynell 1997; Levin et al. 1997; Levin and Keesey 1998). The characterization and selective breeding of these two groups of rats has lead to the identification of differences in food intake, feed efficiency, and the expression level of hypothalamic food intake regulatory peptides (Levin and Dunn-Meynell 1997; Levin et al. 1997). Nonhuman primate studies indicate that there are large differences between individuals in high-fat-diet-induced weight gain and that the individuals with the highest levels of physical activity are the least likely to gain weight (Sullivan et al. 2005; Sullivan et al. 2006). Many investigators are currently using animal models to identify physiological, genetic, and neural circuit influences on susceptibility to diet-induced obesity.

In addition to studies of adult environmental influences on energy balance, intrauterine and early childhood influences are under active study. Although intrauterine environmental influences on susceptibility to obesity were first described in humans (Charney et al. 1976; Chen et al. 2005; Ekelund et al. 2005; Laitinen et al. 2001; Levin 2000; Maffeis et al. 1994; Parsons et al. 2001; Ravelli et al. 1999; Ravelli et al. 1976; Roseboom et al. 2001; Silliman and Kretchmer 1995; Simmons and Breier 2002; Whitaker 2004; Whitelaw 1976), animal models hold promise for providing important insights into the underlying mechanisms. High-fat diet consumption by mothers during pregnancy and lactation has long-term consequences on offspring weight, body fat content, and orexigenic and anorexigenic neuropeptide systems (Guo and Jen 1995; Levin and Govek 1998). Moreover, both maternal undernutrition and maternal type 2 diabetes mellitus during gestation and lactation also predispose adult offspring to obesity and insulin resistance (Fernandez-Twinn et al. 2005; Petry et al. 1997).

The capacity of the early postnatal environmental condition to produce long-term influences on energy balance in adult offspring is another area of active investigation. For example, rat pups from mothers fed a high-fat diet during gestation cross fostered to dams consuming a low-fat diet during lactation became more obese than pups whose mothers consumed a low-fat diet during gestation and were cross fostered to female rats 
consuming a high-fat diet during lactation (Levin 2006). Animal studies have revealed that malnutrition (Jones et al. 1984), insulin injections (Jones et al. 1996), and maternal stress, such as injection of endotoxins and immunosuppressants during gestation, also predispose offspring to adult obesity (Levin 2006). The composition and volume of maternal milk are also important determinants of the development of metabolic regulation (Levin 2006). Milk volume is experimentally increased by reducing the number of pups that a mother feeds. Rodents from small litters become obese and leptin-resistant (Faust et al. 1980; Schmidt et al. 2001; Voits et al. 1996) and eat more (Oscai and McGarr 1978; Plagemann et al. 1992; Plagemann et al. 1999a, b) than rodents from normal-sized litters.

\section{Animal models of BED}

The mechanisms underlying binge eating and the physiologic and neural effects of binge eating are not well understood nor easily studied in humans; thus, the development of animal models of binge eating is important (Corwin and Buda-Levin 2004; Yanovski 1995). As in BN, modeling emotional afflictions such as distress and loss of control are difficult in animals; thus, most of the animal models of BED strive to mimic the central behavioral feature of the disorder: binge eating. The animal models of binge eating are described in detail in the animal models of "Bulimia nervosa" section and include animal models where binging is induced by sham-feeding using a gastric fistula, acute (foot shock, tail pinch) and chronic (space restriction and maternal separation) stressors, cycles of food restriction, and limited access to highly palatable food (Corwin and Buda-Levin 2004).

\section{Animal models of NES}

Currently, animal models of NES have not been developed. A study in nonhuman primates found large differences in night eating between individual monkeys, with some monkeys consuming $60 \%$ of their total calories at night (Sullivan et al. 2005). However, the individuals eating the largest proportion of calories at night did not show an increased propensity to gain weight and were not heavier or fatter than monkeys eating the majority of their daily caloric intake during daytime hours (Sullivan et al. 2005), suggesting that factors other than consumption of calories at night play a role in the predisposition of individuals with NES to obesity. Rodent studies show that feeding during the circadian phase when they normally sleep alters peripheral and central regulation of circadian rhythms (Damiola et al. 2000; Yamazaki et al. 2000). These animal models could be used to examine the metabolic and neuroendocrine consequences of consuming food during the night.

\section{Conclusion}

Although animal models have contributed to the current understanding of the eating disorders AN, BN, and obesity, they have done so in different ways and to different degrees. This is in part due to differences in the extent to which the pathophysiology of these disorders are currently understood. For example, in $\mathrm{AN}$ and $\mathrm{BN}$, the behavioral factors associated with these disorders have been well characterized. However, the behavioral determinants of body weight and energy balance regulation are less well described in humans, with physical activity being one of the determinants. Because self-report data are notoriously unreliable (Champagne et al. 1998; DeLany et al. 2002) and feeding patterns are skewed by the laboratory setting (Mitchell et al. 1998), new approaches are required to characterize feeding/activity phenotypes in human obesity. Although many of the studies characterizing animal models of obesity measure daily food intake, few studies include detailed assessment of physical activity and food intake patterns. Examining the behavioral perturbations of animal models of obesity could provide important insights into behavioral regulation in obese humans. Thus, studies of rodent obesity models would benefit from greater emphasis on the behavioral determinants of energy balance, such as feeding and physical activity.

In contrast, genetic determinants underlying obesity have been much more extensively characterized than those predisposing to either AN or BN. The evidence implicating $\mathrm{MC}_{4} \mathrm{R}$ mutations in human obesity is much stronger than that for any genetic defect in AN or BN. Currently, the ability to use mice to examine genetic etiological factors for $\mathrm{AN}$ and $\mathrm{BN}$ must await breakthroughs in human genetic studies of these disorders.

\section{References}

Alexander J, Chang GQ, Dourmashkin JT, Leibowitz SF (2006) Distinct phenotypes of obesity-prone AKR/J, DBA2J and C57BL/6J mice compared to control strains. Int J Obes (Lond) 30:50-59

Andersson L, Haley CS, Ellegren H, Knott SA, Johansson M, Andersson K, Andersson-Eklund L, Edfors-Lilja I, Fredholm M, Hansson I et al (1994) Genetic mapping of quantitative trait loci for growth and fatness in pigs. Science 263:1771-1774

Asarian L, Geary N (2007) Estradiol enhances cholecystokinindependent lipid-induced satiation and activates estrogen receptor-\{alpha\}-expressing cells in the nucleus tractus solitarius of ovariectomized rats. Endocrinology 148:5656-5666

Avraham Y, Hao S, Mendelson S, Berry E (2001) Tyrosine improves appetite, cognition and exercise tolerance in activity anorexia. Med Sci Sports Exerc 33:2104-2110

Balthasar N, Coppari R, McMinn J, Liu SM, Lee CE, Tang V, Kenny CD, McGovern RA, Chua SC Jr, Elmquist JK, Lowell BB (2004) 
Leptin receptor signaling in POMC neurons is required for normal body weight homeostasis. Neuron 42:983-991

Bell CG, Walley AJ, Froguel P (2005) The genetics of human obesity. Nat Rev Genet 6:221-234

Birketvedt GS, Florholmen J, Sundsfjord J, Osterud B, Dinges D, Bilker W, Stunkard A (1999) Behavioral and neuroendocrine characteristics of the night-eating syndrome. JAMA 282:657-663

Birketvedt GS, Sundsfjord J, Florholmen JR (2002) Hypothalamicpituitary-adrenal axis in the night eating syndrome. Am J Physiol Endocrinol Metab 282:E366-E369

Blundell JE, Leshem MB (1975) The effect of 5-hydroxytryptophan on food intake and on the anorexic and action of amphetamine and fenfluramine. J Pharm Pharmacol 27:31-37

Branson R, Potoczna N, Kral JG, Lentes KU, Hoehe MR, Horber FF (2003) Binge eating as a major phenotype of melanocortin 4 receptor gene mutations. N Engl J Med 348:1096-1103

Brewerton T, Lydiard R, Herzog D, Brotman AW, O’Neil P, Ballenger J (1995) Co-morbidity of axis I diagnoses in bulimia nervosa. J Clin Psychiatry 56:77-80

Brown K, Bujac S, Mann E, Cambell D, Stubbins M, Blundell J (2007) Further evidence of association of OPRD1 \& HTR1D polymorphisms with susceptibility to anorexia nervosa. Biol Psychiatry 61:367-373

Butler AA (2006) The melanocortin system and energy balance. Peptides 27:281-290

Butler AA, Marks DL, Fan W, Kuhn CM, Bartolome M, Cone RD (2001) Melanocortin-4 receptor is required for acute homeostatic responses to increased dietary fat. Nat Neurosci 4:605-611

Casper R (1983) On the emergence of bulimia nervosa as a syndrome: a historical view. Int J Eat Disord 2:3-16

Casper RC (1998a) Biology of eating disorders, 2nd edn. American Psychiatric Press, Washington, DC

Casper RC (1998b) Behavioral activation and lack of concern, core symptoms of anorexia nervosa? Int J Eat Disord 24:381-393

Casper R (2006) The 'drive for activity' and 'restlessness" in anorexia nervosa, potential pathways. J Affect Disord 92:99-107

Casper R, Davis J (1977) On the course of anorexia nervosa. Am J Psychiatry 134:974-978

Casper R, Davis J, Pandey G (1977) The effect of the nutritional status and weight changes on hypothalamic function tests in anorexia nervosa. In: Vigersky R (ed) Anorexia nervosa. Raven, New York, pp 137-149

Casper RC, Halmi KA, Goldberg SC, Eckert ED, Davis JM (1979) Disturbances in body image estimation as related to other characteristics and outcome in anorexia nervosa. Br J Psychiatry 134:60-66

Casper R, Eckert E, Halmi K, Goldberg S, Davis J (1980) Bulimia: its incidence and clinical significance in patients with anorexia nervosa. Arch Gen Psychiatry 37:1030-1035

Casper R, Schoeller D, Kushner R, Hnilicka J, Gold S (1991) Total daily energy expenditure and activity level in anorexia nervosa. Am J Clin Nutr 53:1143-1150

Casper R, Hedeker D, McClough J (1992) Personality dimensions in eating disorders and their relevance for subtyping. J Am Acad Child Adolesc Psychiatry 31:830-840

Champagne CM, Baker NB, DeLany JP, Harsha DW, Bray GA (1998) Assessment of energy intake underreporting by doubly labeled water and observations on reported nutrient intakes in children. J Am Diet Assoc 98:426-433

Charney E, Goodman HC, McBride M, Lyon B, Pratt R (1976) Childhood antecedents of adult obesity. Do chubby infants become obese adults? N Engl J Med 295:6-9

Chen JL, Kennedy C, Yeh CH, Kools S (2005) Risk factors for childhood obesity in elementary school-age Taiwanese children. Prog Cardiovasc Nurs 20:96-103
Cheung CC, Clifton DK, Steiner RA (1997) Proopiomelanocortin neurons are direct targets for leptin in the hypothalamus. Endocrinology 138:4489-4492

Clifton P (2000) Meal patterning in rodents: psychopharmacological and neuroanatomical studies. Neurosci Biobehav Rev 24:213222

Cohen P, Zhao C, Cai X, Montez JM, Rohani SC, Feinstein P, Mombaerts P, Friedman JM (2001) Selective deletion of leptin receptor in neurons leads to obesity. J Clin Invest 108:1113-1121

Colditz GA, Willett WC, Stampfer MJ, Manson JE, Hennekens CH, Arky RA, Speizer FE (1990) Weight as a risk factor for clinical diabetes in women. Am J Epidemiol 132:501-513

Coleman DL (1973) Effects of parabiosis of obese with diabetes and normal mice. Diabetologia 9:294-298

Coleman DL (1978) Obese and diabetes: two mutant genes causing diabetes-obesity syndromes in mice. Diabetologia 14:141-148

Coll AP (2007) Effects of pro-opiomelanocortin (POMC) on food intake and body weight: mechanisms and therapeutic potential? Clin Sci (Lond) 113:171-182

Cone RD (2005) Anatomy and regulation of the central melanocortin system. Nat Neurosci 8:571-578

Corwin RL (2006) Bingeing rats: a model of intermittent excessive behavior? Appetite 46:11-15

Corwin RL, Buda-Levin A (2004) Behavioral models of binge-type eating. Physiol Behav 82:123-130

Crabbe JC, Wahlsten D, Dudek BC (1999) Genetics of mouse behavior: interactions with laboratory environment. Science 284 : $1670-1672$

Crawley JN (1996) Unusual behavioral phenotypes of inbred mouse strains. Trends Neurosci 19:181-182; discussion 188-189

Crisp AH, Kalucy RS (1974) Aspects of the perceptual disorder in anorexia nervosa. Br J Med Psychol 47:349-361

Damiola F, Le Minh N, Preitner N, Kornmann B, Fleury-Olela F, Schibler U (2000) Restricted feeding uncouples circadian oscillators in peripheral tissues from the central pacemaker in the suprachiasmatic nucleus. Genes Dev 14:2950-2961

Dardennes RM, Zizzari P, Tolle V, Foulon C, Kipman A, Romo L, Iancu-Gontard D, Boni C, Sinet PM, Therese Bluet M, Estour B, Mouren MC, Guelfi JD, Rouillon F, Gorwood P, Epelbaum J (2007) Family trios analysis of common polymorphisms in the obestatin/ghrelin, BDNF and AGRP genes in patients with Anorexia nervosa: association with subtype, body-mass index, severity and age of onset. Psychoneuroendocrinology 32:106113

Davey RA, MacLean HE (2006) Current and future approaches using genetically modified mice in endocrine research. Am J Physiol Endocrinol Metab 291:E429-E438

Davis JD, Campbell CS (1973) Peripheral control of meal size in the rat. Effect of sham feeding on meal size and drinking rate. J Comp Physiol Psychol 83:379-387

De Lorenzo A, Tagliabue A, Andreoli A, Testolin G, Comelli M, Deurenberg P (2001) Measured and predicted resting metabolic rate in Italian males and females, aged 18-59 y. Eur J Clin Nutr $55: 208-214$

DeLany JP, Bray GA, Harsha DW, Volaufova J (2002) Energy expenditure in preadolescent African American and white boys and girls: the Baton Rouge Children's Study. Am J Clin Nutr 75:705-713

DSM (2000) Diagnostic and statistical manual of mental disorders IVTR, 4th edn. American Psychiatric Association, Washington, DC

DSM I (1994) Diagnostic and statistical manual of mental disorders, 4th edn. American Psychiatric Association, Washington, DC

Eckert E, Pomeroy C, Raymond N, Kohler P, Thuras P, Bowers C (1998) Leptin in anorexia nervosa. J Clin Endocrinol Metab 83:791-795 
Ekelund U, Neovius M, Linne Y, Brage S, Wareham NJ, Rossner S (2005) Associations between physical activity and fat mass in adolescents: the Stockholm weight development study. Am J Clin Nutr 81:355-360

Ellacott KL, Cone RD (2006) The role of the central melanocortin system in the regulation of food intake and energy homeostasis: lessons from mouse models. Philos Trans R Soc Lond B Biol Sci 361:1265-1274

Elmquist JK, Elias CF, Saper CB (1999) From lesions to leptin: hypothalamic control of food intake and body weight. Neuron 22:221-232

Epling WF, Pierce WD (1988) Activity-based anorexia: a biobehavioral perspective. Int J Eat Dis 1988:475-485

Erickson JC, Clegg KE, Palmiter RD (1996) Sensitivity to leptin and susceptibility to seizures of mice lacking neuropeptide Y. Nature 381:415-421

Farooqi IS, O'Rahilly S (2005a) Monogenic obesity in humans. Annu Rev Med 56:443-458

Farooqi IS, O'Rahilly S (2005b) New advances in the genetics of early onset obesity. Int J Obes (Lond) 29:1149-1152

Farooqi IS, Keogh JM, Yeo GS, Lank EJ, Cheetham T, O'Rahilly S (2003) Clinical spectrum of obesity and mutations in the melanocortin 4 receptor gene. N Engl J Med 348:1085-1095

Faust IM, Johnson PR, Hirsch J (1980) Long-term effects of early nutritional experience on the development of obesity in the rat. J Nutr 110:2027-2034

Fernandez-Twinn DS, Wayman A, Ekizoglou S, Martin MS, Hales CN, Ozanne SE (2005) Maternal protein restriction leads to hyperinsulinemia and reduced insulinsignaling protein expression in 21mo-old female rat offspring. Am J Physiol Regul Integr Comp Physiol 288:R368-R373

Fetissov SO, Bergstrom U, Johansen JE, Hokfelt T, Schalling M, Ranscht B (2005) Alterations of arcuate nucleus neuropeptidergic development in contactindeficient mice: comparison with anorexia and food-deprived mice. Eur J Neurosci 22:3217-3228

Fetoui H, Bouaziz H, Mahjoubi-Sa A, Soussia L, Guermazi F, Zeghal N (2006) Food restriction induced thyroid changes and their reversal after refeeding in female rats and their pups. Acta Biol Hung $57: 391-402$

Flegal KM, Carroll MD, Ogden CL, Johnson CL (2002) Prevalence and trends in obesity among US adults, 1999-2000. JAMA 288:1723-1727

Folsom AR, Jacobs DR Jr, Wagenknecht LE, Winkhart SP, Yunis C, Hilner JE, Savage PJ, Smith DE, Flack JM (1996) Increase in fasting insulin and glucose over seven years with increasing weight and inactivity of young adults. The CARDIA Study. Coronary artery risk development in young adults. Am J Epidemiol 144:235-246

Foltin RW, Moran TH (1989) Food intake in baboons: effects of a long-acting cholecystokinin analog. Appetite 12:145-152

Frankenfield DC, Muth ER, Rowe WA (1998) The Harris-Benedict studies of human basal metabolism: history and limitations. J Am Diet Assoc 98:439-445

Friedman JM (2003) A war on obesity, not the obese. Science 299:856-858

Friedman JM, Leibel RL, Siegel DS, Walsh J, Bahary N (1991) Molecular mapping of the mouse ob mutation. Genomics 11: $1054-1062$

Frieling $\mathrm{H}$, Romer $\mathrm{KD}$, Wilhelm $\mathrm{J}$, Hillemacher $\mathrm{T}$, Kornhuber $\mathrm{J}$, de Zwaan M, Jacoby GE, Bleich S (2006) Association of catecholamine-O-methyltransferase and 5-HTTLPR genotype with eating disorder-related behavior and attitudes in females with eating disorders. Psychiatr Genet 16:205-208

Funkat A, Massa CM, Jovanovska V, Proietto J, Andrikopoulos S (2004) Metabolic adaptations of three inbred strains of mice
(C57BL/6, DBA/2, and 129T2) in response to a high-fat diet. J Nutr 134:3264-3269

Garfinkel P (1974) Perception of hunger and satiety in anorexia nervosa. Psychol Med 4:309-315

Garthwaite TL, Martinson DR, Tseng LF, Hagen TC, Menahan LA (1980) A longitudinal hormonal profile of the genetically obese mouse. Endocrinology 107:671-676

Gelegen C, Collier D, Cambell I, Opelaar H, van den Heuvel J, Adan R, Kas M (2007) Difference in susceptibility to activity-based anorexia in two inbred strains of mice. Eur Neuropsychopharmacol 17:199-205

Gerlai R (1996) Gene-targeting studies of mammalian behavior: is it the mutation or the background genotype? Trends Neurosci 19: $177-181$

Ghosh K, Van Duyne GD (2002) Cre-loxP biochemistry. Methods 28:374-383

Giovannucci E, Ascherio A, Rimm EB, Colditz GA, Stampfer MJ, Willett WC (1995) Physical activity, obesity, and risk for colon cancer and adenoma in men. Ann Intern Med 122:327-334

Gluck ME, Geliebter A, Satov T (2001) Night eating syndrome is associated with depression, low self-esteem, reduced daytime hunger, and less weight loss in obese outpatients. Obes Res 9:264-267

Gould E, Bres M (1986) Regurgitation in gorillas: possible model for human eating disorders (rumination/bulimia). J Dev Behav Pediatr 7:314-319

Grilo CM, Masheb RM (2004) Night-time eating in men and women with binge eating disorder. Behav Res Ther 42:397-407

Grinker JA, Drewnowski A, Enns M, Kissileff H (1980) Effects of d-amphetamine and fenfluramine on feeding pattens and activity of obese and lean Zucker rats. Pharmacol Biochem Behav 12: 265-275

Guo F, Jen KL (1995) High-fat feeding during pregnancy and lactation affects offspring metabolism in rats. Physiol Behav 57:681-686

Hagan W, Wauford P, Chandler P, Jarrett L, Ryback R, Blackburn K (2002) A new animal model of binge eating: key synergistic role of past caloric restriction and stress. Physiol Behav 77:45-54

Halaas JL, Gajiwala KS, Maffei M, Cohen SL, Chait BT, Rabinowitz D, Lallone RL, Burley SK, Friedman JM (1995) Weight-reducing effects of the plasma protein encoded by the obese gene. Science 269:543-546

Halmi KA, Tozzi F, Thornton LM, Crow S, Fichter MM, Kaplan AS, Keel P, Klump KL, Lilenfeld LR, Mitchell JE, Plotnicov KH, Pollice C, Rotondo A, Strober M, Woodside DB, Berrettini WH, Kaye WH, Bulik CM (2005) The relation among perfectionism, obsessive-compulsive personality disorder and obsessivecompulsive disorder in individuals with eating disorders. Int J Eat Disord 38:371-374

Hamm P, Shekelle RB, Stamler J (1989) Large fluctuations in body weight during young adulthood and twenty-five-year risk of coronary death in men. Am J Epidemiol 129:312-318

Hao S, Avraham Y, Bonne O, Berry E (2001) Separation-induced body weight loss, impairment in alternation behavior, and autonomic tone:effects of tyrosine. Pharmacol Biochem Behav 68:273-281

Hatsukami D, Eckert E, Mitchell J, Pyle R (1984) Affective disorder and substance abuse in women with bulimia. Psychol Med 14:701-704

Hebebrand J, Blum W, Barth N et al (1997) Leptin levels in patients with anorexia nervosa are reduced in the acute stage and elevated upon short-term weight restoration. Mol Psychiatry 2:330-334

Hebebrand J, Exner C, Casper R, Hebebrand K, Holtkamp C, Remschmidt H, Herpertz-Dahlman B, Klingenspor M (2003a) Hyperactivity in patients with anorexia nervosa and in semi- 
starved rats: evidence for a pivotal role of hypoleptinemia. Physiol Behav 6957:1-13

Hebebrand J, Friedel S, Schauble N, Geller F, Hinney A (2003b) Perspectives: molecular genetic research in human obesity. Obes Rev 4:139-146

Hebebrand J, Casper R, Treasure J, Schweiger U (2004) The need to revise the diagnostic criteria for anorexia nervosa. J Neural Transm 111:827-840

Hillebrand J, Koener M, de Rijke C, Kas M, Adan R (2005) Leptin treatment in activity based anorexia. Biol Psychiatry 58:165-171

Hudson JI, Hiripi E, Pope HG Jr, Kessler RC (2007) The prevalence and correlates of eating disorders in the National Comorbidity Survey Replication. Biol Psychiatry 61:348-358

Huszar D, Lynch CA, Fairchild-Huntress V, Dunmore JH, Fang Q, Berkemeier LR, Gu W, Kesterson RA, Boston BA, Cone RD, Smith FJ, Campfield LA, Burn P, Lee F (1997) Targeted disruption of the melanocortin-4 receptor results in obesity in mice. Cell 88:131-141

Inoue K, Iwasaki S, Muramatsu T, Yamauchi T, Kiriike N (2006) Animal model of eating disorders. Nihon Shinkei Seishin Yakurigaku Zasshi 26:89-92

Jarosz PA, Metzger BL (2002) The effect of opioid antagonism on food intake behavior and body weight in a biobehavioral model of obese binge eating. Biol Res Nurs 3:198-209

Johansen J, Fetissov S, Fisher H, Arvidsson S, Hokfelt T, Schalling M (2003) Approaches to anorexia in rodents: focus on the anx/anx mouse. Eur J Pharmacol 480:171-176

Jones AP, Simson EL, Friedman MI (1984) Gestational undernutrition and the development of obesity in rats. J Nutr 114:1484-1492

Jones AP, Olster DH, States B (1996) Maternal insulin manipulations in rats organize body weight and noradrenergic innervation of the hypothalamus in gonadally intact male offspring. Brain Res Dev Brain Res 97:16-21

Kanarek RB, Collier GH (1983) Self-starvation: a problem of overriding the satiety signal? Physiol Behav 30:307-311

Kask A, Rago L, Mutulis F, Pahkla R, Wikberg JE, Schioth HB (1998a) Selective antagonist for the melanocortin 4 receptor (HS014) increases food intake in freefeeding rats. Biochem Biophys Res Commun 245:90-93

Kask A, Rago L, Wikberg JE, Schioth HB (1998b) Evidence for involvement of the melanocortin MC4 receptor in the effects of leptin on food intake and body weight. Eur J Pharmacol 360:15-19

Keys A, Brozek J, Henschel A, Mickelsen O, Taylor H (1950) The biology of human starvation. University of Minnesota Press, Minneapolis

Kissileff HR, Zimmerli EJ, Torres MI, Devlin MJ, Walsh BT (2007) Effect of eating rate on binge size in bulimia nervosa. Physiol Behav (in press), Oct. 12

Klein S, Burke LE, Bray GA, Blair S, Allison DB, Pi-Sunyer X, Hong Y, Eckel RH (2004) Clinical implications of obesity with specific focus on cardiovascular disease: a statement for professionals from the American heart association council on nutrition, physical activity, and metabolism: endorsed by the American College of Cardiology Foundation. Circulation 110:2952-2967

Klein DA, Mayer LE, Schebendach JE, Walsh BT (2007) Physical activity and cortisol in anorexia nervosa. Psychoneuroendocrinology 32:539-547

Klump KL, Gobrogge KL (2005) A review and primer of molecular genetic studies of anorexia nervosa. Int J Eat Disord 37(Suppl): S43-S48; discussion S87-S89

Krude H, Biebermann H, Luck W, Horn R, Brabant G, Gruters A (1998) Severe earlyonset obesity, adrenal insufficiency and red hair pigmentation caused by POMC mutations in humans. Nat Genet 19:155-157

Kuczmarski RJ, Ogden CL, Guo SS, Grummer-Strawn LM, Flegal KM, Mei Z, Wei R, Curtin LR, Roche AF, Johnson CL (2002) 2000
CDC growth charts for the United States: methods and development. Vital Health Stat 11:1-190

Kujala UM, Kaprio J, Taimela S, Sarna S (1994) Prevalence of diabetes, hypertension, and ischemic heart disease in former elite athletes. Metabolism 43:1255-1260

Kyriakis S, Olsson N, Martinsson K, Bjork A (1990) Thin sow syndrome (TSS). Br Vet J 146:463-467

Laitinen J, Power C, Jarvelin MR (2001) Family social class, maternal body mass index, childhood body mass index, and age at menarche as predictors of adult obesity. Am J Clin Nutr 74:287294

Lathe R (1996) Mice, gene targeting and behaviour: more than just genetic background. Trends Neurosci 19:183-186; discussion 188-189

Levin BE (1990) Obesity-prone and -resistant rats differ in their brain $[3 \mathrm{H}]$ paraminoclonidine binding. Brain Res 512:54-59

Levin BE (2000) Metabolic imprinting on genetically predisposed neural circuits perpetuates obesity. Nutrition 16:909-915

Levin BE (2006) Metabolic imprinting: critical impact of the perinatal environment on the regulation of energy homeostasis. Philos Trans R Soc Lond B Biol Sci 361:1107-1121

Levin BE, Dunn-Meynell AA (1997) Dysregulation of arcuate nucleus preproneuropeptide Y mRNA in diet-induced obese rats. Am J Physiol 272:R1365-R1370

Levin BE, Govek E (1998) Gestational obesity accentuates obesity in obesity-prone progeny. Am J Physiol 275:R1374-R1379

Levin BE, Keesey RE (1998) Defense of differing body weight set points in diet-induced obese and resistant rats. Am J Physiol 274: R412-R419

Levin BE, Dunn-Meynell AA, Balkan B, Keesey RE (1997) Selective breeding for dietinduced obesity and resistance in SpragueDawley rats. Am J Physiol 273:R725-R730

Levine JA (2004) Nonexercise activity thermogenesis (NEAT): environment and biology. Am J Physiol Endocrinol Metab 286: E675-E685

Lu D, Willard D, Patel IR, Kadwell S, Overton L, Kost T, Luther M, Chen W, Woychik RP, Wilkison WO et al (1994) Agouti protein is an antagonist of the melanocytestimulating-hormone receptor. Nature 371:799-802

Lubrano-Berthelier C, Cavazos M, Le Stunff C, Haas K, Shapiro A, Zhang S, Bougneres P, Vaisse C (2003) The human MC4R promoter: characterization and role in obesity. Diabetes 52:29963000

Lundgren JD, Allison KC, Stunkard AJ (2006) Familial aggregation in the night eating syndrome. Int J Eat Disord 39:516-518

Maffeis C, Micciolo R, Must A, Zaffanello M, Pinelli L (1994) Parental and perinatal factors associated with childhood obesity in north-east Italy. Int J Obes Relat Metab Disord 18:301-305

Mahoney LB, Denny CA, Seyfried TN (2006) Caloric restriction in C57BL/6J mice mimics therapeutic fasting in humans. Lipids Health Dis 5:13

Manson JE, Colditz GA, Stampfer MJ, Willett WC, Rosner B, Monson RR, Speizer FE, Hennekens CH (1990) A prospective study of obesity and risk of coronary heart disease in women. $\mathrm{N}$ Engl J Med 322:882-889

Marcus MD, Wing RR, Lamparski DM (1985) Binge eating and dietary restraint in obese patients. Addict Behav 10:163-168

Marsh DJ, Hollopeter G, Kafer KE, Palmiter RD (1998) Role of the Y5 neuropeptide Y receptor in feeding and obesity. Nat Med 4:718-721

Mayer J, Russell RE, Bates MW, Dickie MM (1953) Metabolic, nutritional and endocrine studies of the hereditary obesitydiabetes syndrome of mice and mechanism of its development. Metabolism 2:9-21

McElroy S, Hudson J, Capece J, Beyers K, Fisher A, Rosenthal N (2007) Topiramate for the treatment of binge eating disorder 
associated with obesity: a placebo-controlled study. Biol Psychiatry 61:1039-1048

McGuirk J, Goodall E, Silverstone T, Willner P (1991) Differential effects of dfenfluramine and d-amphetamine on the microstructure of human eating behavior. Behav Pharmacol 2:113-119

Miller KJ (2005) Serotonin 5-ht2c receptor agonists: potential for the treatment of obesity. Mol Interv 5:282-291

Miltenberger RJ, Mynatt RL, Wilkinson JE, Woychik RP (1997) The role of the agouti gene in the yellow obese syndrome. J Nutr 127:1902S-1907S

Mitchell JE, Crow S, Peterson CB, Wonderlich S, Crosby RD (1998) Feeding laboratory studies in patients with eating disorders: a review. Int J Eat Disord 24:115-124

Mokdad AH, Marks JS, Stroup DF, Gerberding JL (2004) Actual causes of death in the United States, 2000. JAMA 291:12381245

Monteleone P, Santonastoso P, Mauri M, Bellodi L, Erzegovesi S, Fuschino A, Favaro A, Rotondo A, Castalso E, Maj M (2006a) Investigation of the serotonin transporter regulatory region polymorphism in bulimia nervosa: relationships to harm avoidance, nutritional parameters, and psychiatric comorbidity. Psychosom Med 68:99-103

Monteleone P, Tortorella A, Castaldo E, Di Filippo C, Maj M (2006b) No association of the Arg51Gln and Leu72Met polymorphisms of the ghrelin gene with anorexia nervosa or bulimia nervosa. Neurosci Lett 398:325-327

Mook D (1963) Oral and postingestional determinants of the intake of various solutions in rats with oesophageal fistulas. J Comp Physiol Psychol 56:645-649

Murphy B, Nunes CN, Ronan JJ, Harper CM, Beall MJ, Hanaway M, Fairhurst AM, Van der Ploeg LH, MacIntyre DE, Mellin TN (1998) Melanocortin mediated inhibition of feeding behavior in rats. Neuropeptides 32:491-497

Naessen S, Carlstrom K, Bystrom B, Pierre Y, Hirschberg AL (2007) Effects of an antiandrogenic oral contraceptive on appetite and eating behavior in bulimic women. Psychoneuroendocrinology 32:548-554

Nergardh R, Ammar A, Brodin U, Bergstrom J, Scheurink A, Sodersten P (2007) Neuropeptide Y facilitates activity-basedanorexia. Psychoneuroendocrinology 32:493-502

NIH (1998) Clinical guidelines on the identification, evaluation, and treatment of overweight and obesity in adults - the evidence report. national institutes of health. Obes Res 6(Suppl 2):51S$209 \mathrm{~S}$

Nonogaki K, Strack A, Dallman M, Tecott LH (1998) Leptininsensitive hyperphagia and type 2 diabetes in mice with a mutated serotonin 5-HT2C receptor gene. Nat Med 4:1152-1156

Nylander I (1971) The feeling of being fat and dieting in a school population: epidemiologic interview investigation. Acta Sociomed Scand 3:17-26

Ogden CL, Carroll MD, Curtin LR, McDowell MA, Tabak CJ, Flegal KM (2006) Prevalence of overweight and obesity in the United States, 1999-2004. JAMA 295:1549-1555

Ogden CL, Yanovski SZ, Carroll MD, Flegal KM (2007) The epidemiology of obesity. Gastroenterology 132:2087-2102

Oscai LB, McGarr JA (1978) Evidence that the amount of food consumed in early life fixes appetite in the rat. Am J Physiol 235: R141-R144

O'Reardon JP, Allison KC, Martino NS, Lundgren JD, Heo M, Stunkard AJ (2006) A randomized, placebo-controlled trial of sertraline in the treatment of night eating syndrome. Am J Psychiatry 163:893-898

Paffenbarger RS Jr, Hyde RT, Wing AL, Lee IM, Jung DL, Kampert JB (1993) The association of changes in physical-activity level and other lifestyle characteristics with mortality among men. N Engl J Med 328:538-545
Papaleo F, Kieffer BL, Tabarin A, Contarino A (2007) Decreased motivation to eat in mu-opioid receptor-deficient mice. Eur J Neurosci 25:3398-3405

Paré W (1975) The influence of food consumption and running activity on the activitystress ulcer in the rat. Dig Dis 20:262-273

Parry-Jones B (1994) Mercycism or rumination disorder. A historical investigation and current assessment. Br J Psychiatry 165:303314

Parsons TJ, Power C, Manor O (2001) Fetal and early life growth and body mass index from birth to early adulthood in 1958 British cohort: longitudinal study. BMJ 323:1331-1335

Pedrazzini T, Seydoux J, Kunstner P, Aubert JF, Grouzmann E, Beermann F, Brunner HR (1998) Cardiovascular response, feeding behavior and locomotor activity in mice lacking the NPY Y1 receptor. Nat Med 4:722-726

Pelleymounter MA, Cullen MJ, Baker MB, Hecht R, Winters D, Boone T, Collins F (1995) Effects of the obese gene product on body weight regulation in ob/ob mice. Science 269:540-543

Petry CJ, Ozanne SE, Wang CL, Hales CN (1997) Early protein restriction and obesity independently induce hypertension in 1-year-old rats. Clin Sci (Lond) 93:147-152

Pirke K, Ploog D (1987) Biology of human starvation. In: Beumont P, Burrows G, Casper R (eds) Eating disorders: anorexia and bulimia nervosa. Elsevier, Amsterdam, pp 80-102

Pirke KM, Trimborn P, Platte P, Fichter M (1991) Average total energy expenditure in anorexia nervosa, bulimia nervosa, and healthy young women. Biol Psychiatry 30:711-718

Pirke K, Brooks A, Wilckens T, Marquard A, Schweiger U (1993) Starvation-induced hyperactivity in the rat: the role of endocrine and neurotransmitter changes. Neurosci Biobehav Rev 17:287294

Plagemann A, Heidrich I, Gotz F, Rohde W, Dorner G (1992) Obesity and enhanced diabetes and cardiovascular risk in adult rats due to early postnatal overfeeding. Exp Clin Endocrinol 99:154-158

Plagemann A, Harder T, Rake A, Voits M, Fink H, Rohde W, Dorner G (1999a) Perinatal elevation of hypothalamic insulin, acquired malformation of hypothalamic galaninergic neurons, and syndrome $\mathrm{x}$-like alterations in adulthood of neonatally overfed rats. Brain Res 836:146-155

Plagemann A, Harder T, Rake A, Waas T, Melchior K, Ziska T, Rohde W, Dorner G (1999b) Observations on the orexigenic hypothalamic neuropeptide Y-system in neonatally overfed weanling rats. J Neuroendocrinol 11:541-546

Quinton N, Meechan D, Brown K, Eastwood H, Blakemore A (2004) Single nucleotide polymorphisms in the leptin receptor gene: studies in anorexia nervosa. Psychiatr Genet 14:191-194

Rand CS, Macgregor AM, Stunkard AJ (1997) The night eating syndrome in the general population and among postoperative obesity surgery patients. Int J Eat Disord 22:65-69

Rankinen T, Perusse L, Weisnagel SJ, Snyder EE, Chagnon YC, Bouchard C (2002) The human obesity gene map: the 2001 update. Obes Res 10:196-243

Ravelli GP, Stein ZA, Susser MW (1976) Obesity in young men after famine exposure in utero and early infancy. $\mathrm{N}$ Engl $\mathrm{J}$ Med 295:349-353

Ravelli AC, van Der Meulen JH, Osmond C, Barker DJ, Bleker OP (1999) Obesity at the age of $50 \mathrm{y}$ in men and women exposed to famine prenatally. Am J Clin Nutr 70:811-816

Ravussin E, Gautier JF (1999) Metabolic predictors of weight gain. Int J Obes Relat Metab Disord 23(Suppl 1):37-41

Ribases M, Gratacos M, Armengol L, de Cid R, Badia A, Jimenez L, Solano R, Vallejo J, Fernandez F, Estivill X (2003) Met66 in the brain-derived neurotrophic factor (BDNF) precursor is associated with anorexia nervosa restrictive type. Mol Psychiatry 8:745-751

Ribases M, Gratacos M, Fernandez-Aranda F, Bellodi L, Boni C, Anderluh M, Cavallini MC, Cellini E, Di Bella D, Erzegovesi S, 
Foulon C, Gabrovsek M, Gorwood P, Hebebrand J, Hinney A, Holliday J, Hu X, Karwautz A, Kipman A, Komel R, Nacmias B, Remschmidt H, Ricca V, Sorbi S, Wagner G, Treasure J, Collier DA, Estivill X (2004) Association of BDNF with anorexia, bulimia and age of onset of weight loss in six European populations. Hum Mol Genet 13:1205-1212

Ribases M, Gratacos M, Fernandez-Aranda F, Bellodi L, Boni C, Anderluh M, Cristina Cavallini M, Cellini E, Di Bella D, Erzegovesi S, Foulon C, Gabrovsek M, Gorwood P, Hebebrand J, Hinney A, Holliday J, Hu X, Karwautz A, Kipman A, Komel R, Nacmias B, Remschmidt H, Ricca V, Sorbi S, Tomori M, Wagner G, Treasure J, Collier DA, Estivill X (2005) Association of BDNF with restricting anorexia nervosa and minimum body mass index: a family-based association study of eight European populations. Eur J Hum Genet 13:428-434

Rikke BA, Johnson TE (2007) The physiological genetics of dietary restriction: uncoupling the body temperature and body weight responses. Am J Physiol Regul Integr Comp Physiol 293:R1522R1527

Rimm EB, Stampfer MJ, Giovannucci E, Ascherio A, Spiegelman D, Colditz GA, Willett WC (1995) Body size and fat distribution as predictors of coronary heart disease among middle-aged and older US men. Am J Epidemiol 141:1117-1127

Rogers PJ, Blundell JE (1979) Effect of anorexic drugs on food intake and the microstructure of eating in human subjects. Psychopharmacology 66:159-165

Roseboom TJ, van der Meulen JH, Ravelli AC, Osmond C, Barker DJ, Bleker OP (2001) Effects of prenatal exposure to the Dutch famine on adult disease in later life: an overview. Mol Cell Endocrinol 185:93-98

Rosenhagen MC, Uhr M, Schussler P, Steiger A (2005) Elevated plasma ghrelin levels in night-eating syndrome. Am J Psychiatry $162: 813$

Routtenberg A, Kuznesof AW (1967) Self-starvation of rats living in activity wheels on a restricted feeding schedule. J Comp Physiol Psychol 64:414-421

Russell G (1979) Bulimia nervosa: an ominous variant of anorexia nervosa. Psychol Med 9:429-448

Salton SR, Hahm S, Mizuno TM (2000) Of mice and MEN: what transgenic models tell us about hypothalamic control of energy balance. Neuron 25:265-268

Schmidt I, Fritz A, Scholch C, Schneider D, Simon E, Plagemann A (2001) The effect of leptin treatment on the development of obesity in overfed suckling Wistar rats. Int J Obes Relat Metab Disord 25:1168-1174

Seeley RJ, Yagaloff KA, Fisher SL, Burn P, Thiele TE, van Dijk G, Baskin DG, Schwartz MW (1997) Melanocortin receptors in leptin effects. Nature 390:349

Shroff H, Reba L, Thornton LM, Tozzi F, Klump KL, Berrettini WH, Brandt $\mathrm{H}$, Crawford S, Crow S, Fichter MM, Goldman D, Halmi KA, Johnson C, Kaplan AS, Keel P, LaVia M, Mitchell J, Rotondo A, Strober M, Treasure J, Woodside DB, Kaye WH, Bulik CM (2006) Features associated with excessive exercise in women with eating disorders. Int J Eat Disord 39:454-461

Sibilia M, Wagner EF (1995) Strain-dependent epithelial defects in mice lacking the EGF receptor. Science 269:234-238

Siegfried Z, Berry EM, Hao S, Avraham Y (2003) Animal models in the investigation of anorexia. Physiol Behav 79:39-45

Silliman K, Kretchmer N (1995) Maternal obesity and body composition of the neonate. Biol Neonate 68:384-393

Simmons D, Breier BH (2002) Adult obesity and growth in childhood. Fuel mediated teratogenesis driven by maternal obesity may be responsible for pandemic of obesity. BMJ 324:674

Simpson EM, Linder CC, Sargent EE, Davisson MT, Mobraaten LE, Sharp JJ (1997) Genetic variation among 129 substrains and its importance for targeted mutagenesis in mice. Nat Genet 16:19-27
Skuladottir GV, Jonsson L, Skarphedinsson JO, Mutulis F, Muceniece R, Raine A, Mutule I, Helgason J, Prusis P, Wikberg JE, Schioth HB (1999) Long term orexigenic effect of a novel melanocortin 4 receptor selective antagonist. Br J Pharmacol 126:27-34

Smith G (1989) Animal models of human eating disorders. In: Schneider L, Cooper S, Halmi K (eds) The psychobiology of human eating disorders. New York Academy of Sciences, New York, pp 63-74

Smith BM, Thomsen WJ, Grottick AJ (2006) The potential use of selective 5-HT2C agonists in treating obesity. Expert Opin Investig Drugs 15:257-266

Speakman JR, Selman C (2003) Physical activity and resting metabolic rate. Proc Nutr Soc 62:621-634

Speakman J, Hambly C, Mitchell S, Krol E (2007) Animal models of obesity. Obes Rev 8(Suppl 1):55-61

Striegel-Moore RH, Franko DL (2003) Epidemiology of binge eating disorder. Int J Eat Disord 34(Suppl):S19-S29

Strober M (1980) Personality and symptomatological features in young nonchronic anorexia patients. J Psychosom Res 24:353359

Strober M, Humphrey L (1987) Familial contributions to the etiology and course of anorexia nervosa and bulimia. J Consult Clin Psychol 65:654-659

Strober M, Freeman R, Bower S, Rigali J (1996) Binge eating in anorexia nervosa predicts later onset of substance use disorder: a ten-year prospective, longitudinal follow-up of 95 adolescents. J Youth Adolesc 25:519-532

Strychar I (2006) Diet in the management of weight loss. CMAJ 174:56-63

Stunkard AJ, Allison KC (2003a) Binge eating disorder: disorder or marker? Int J Eat Disord 34(Suppl):S107-S116

Stunkard AJ, Allison KC (2003b) Two forms of disordered eating in obesity: binge eating and night eating. Int $\mathrm{J}$ Obes Relat Metab Disord 27:1-12

Stunkard AJ, Grace WJ, Wolff HG (1955) The night-eating syndrome; a pattern of food intake among certain obese patients. Am J Med 19:78-86

Stunkard AJ, Allison KC, Lundgren JD, Martino NS, Heo M, Etemad B, O'Reardon JP (2006) A paradigm for facilitating pharmacotherapy at a distance: sertraline treatment of the night eating syndrome. J Clin Psychiatry 67:1568-1572

Sullivan EL, Daniels AJ, Koegler FH, Cameron JL (2005) Evidence in female Rhesus monkeys (Macaca mulatta) that nighttime caloric intake is not associated with weight gain. Obes Res 13:20722080

Sullivan EL, Koegler FH, Cameron JL (2006) Individual differences in physical activity are closely associated with changes in body weight in adult female Rhesus monkeys (Macaca mulatta). Am J Physiol Regul Integr Comp Physiol 291:R633-R642

Surwit RS, Feinglos MN, Rodin J, Sutherland A, Petro AE, Opara EC, Kuhn CM, Rebuffe-Scrive M (1995) Differential effects of fat and sucrose on the development of obesity and diabetes in C57BL/6J and A/J mice. Metabolism 44:645-651

Takeda H, Tsuji M, Hayashi M, Yamada T, Matsumiya T, Koizumi M, Kimura S (2003) Pathophysiologic characteristics of the activitystress paradigm in animal models: inhibitory effect of glucose on these responses. Nutr Rev 61:S57-S59

Tecott LH, Sun LM, Akana SF, Strack AM, Lowenstein DH, Dallman MF, Julius D (1995) Eating disorder and epilepsy in mice lacking 5-HT2c serotonin receptors. Nature 374:542-546

Threadgill DW, Dlugosz AA, Hansen LA, Tennenbaum T, Lichti U, Yee D, LaMantia C, Mourton T, Herrup K, Harris RC et al (1995) Targeted disruption of mouse EGF receptor: effect of genetic background on mutant phenotype. Science 269:230-234

Treasure J, Owen J (1997) Intriguing links between animal behavior and anorexia nervosa. Int J Eat Disord 21:307-311 
Vaisse C, Clement K, Durand E, Hercberg S, Guy-Grand B, Froguel P (2000) Melanocortin-4 receptor mutations are a frequent and heterogeneous cause of morbid obesity. J Clin Invest 106:253262

van Elburg AA, Kas MJ, Hillebrand JJ, Eijkemans RJ, van Engeland $\mathrm{H}$ (2007) The impact of hyperactivity and leptin on recovery from anorexia nervosa. J Neural Transm 114:1233-1237

van Kuyck K, Casteels C, Vermaelen P, Bormans G, Nuttin B, Van Laere K (2007) Motor- and food-related metabolic cerebral changes in the activity-based rat model for anorexia nervosa: a voxel-based microPET study. NeuroImage 35:214-221

Voits M, Forster S, Rodel S, Voigt JP, Plagemann A, Fink H (1996) Obesity induced by unspecific early postnatal overfeeding in male and female rats: hypophagic effect of CCK-8S. Naunyn Schmiedebergs Arch Pharmacol 354:374-378

Wang S (2002) Effects of restraint stress and serotonin on macronutrient selection: a rat model of stress-induced anorexia. Eat Weight Disord 7:23-31

Watanabe K, Hara C, Ogawa N (1992) Feeding conditions and estrous cycle of female rats under the activity-stress procedure and aspects of anorexia nervosa. Physiol Behav 51:827-832

Waxman A (2004) WHO global strategy on diet, physical activity and health. Food Nutr Bull 25:292-302

Whitaker RC (2004) Predicting preschooler obesity at birth: the role of maternal obesity in early pregnancy. Pediatrics 114:e29-e36

Whitelaw AG (1976) Influence of maternal obesity on subcutaneous fat in the newborn. Br Med J 1:985-986
World Health Organization (2000) Obesity: preventing and managing the global epidemic. Report of a WHO consultation. World Health Organ Tech Rep Ser 894:i-xii, 1-253

Willett WC, Manson JE, Stampfer MJ, Colditz GA, Rosner B, Speizer FE, Hennekens CH (1995) Weight, weight change, and coronary heart disease in women. Risk within the 'normal' weight range. JAMA 273:461-465

Wilson MA, Tonegawa S (1997) Synaptic plasticity, place cells and spatial memory: study with second generation knockouts. Trends Neurosci 20:102-106

Yamazaki S, Numano R, Abe M, Hida A, Takahashi R, Ueda M, Block GD, Sakaki Y, Menaker M, Tei H (2000) Resetting central and peripheral circadian oscillators in transgenic rats. Science 288:682-685

Yanovski SZ (1993) Binge eating disorder: current knowledge and future directions. Obes Res 1:306-324

Yanovski SZ (1995) Biological correlates of binge eating. Addict Behav 20:705-712

Zhang Y, Proenca R, Maffei M, Barone M, Leopold L, Friedman JM (1994) Positional cloning of the mouse obese gene and its human homologue. Nature 372:425-432

Ziegler RG, Hoover RN, Nomura AM, West DW, Wu AH, Pike MC, Lake AJ, Horn-Ross PL, Kolonel LN, Siiteri PK, Fraumeni JF Jr (1996) Relative weight, weight change, height, and breast cancer risk in Asian-American women. J Natl Cancer Inst 88:650-660

Zimmerli EJ, Walsh BT, Guss JL, Devlin MJ, Kissileff HR (2006) Gastric compliance in bulimia nervosa. Physiol Behav 87:441-446 